\title{
SHAPE AND STRENGTH OF RED HAVEN PEACHES AT THE DIFFERENT STAGES OF THEIR MATURITY
}

\author{
L. Severa \\ Received: January 14, 2008
}

\begin{abstract}
SEVERA, L.: Shape and strength of Red Haven peaches at the different stages of their maturity. Acta univ. agric. et silvic. Mendel. Brun., 2008, LVI, No. 4, pp. 161-168

Global shape of the peaches of the Red Haven variety (harvested on different days during July, 2007) has been characterized by calculating the $H / D$ s, $H / D c$ and $D c / D s$ ratios. There is no, or nearly no, differences between peaches harvested at the different days. The shape of the all tested peaches was very close to round one. The more detailed description of the peach shape is based on the Elliptic Fourier analysis (EFDs) of the digital photos. The knowledge of the parameters (curvature etc.) is very useful e.g. for the evaluation of the results of the strength tests. Compression tests have been also perforemd - the whole peaches have been compressed between two plates at the constant cross-head velocity $20 \mathrm{~mm} / \mathrm{min}$. The force-displacement curves are characterised by certain monotonic increase and the point called bioyield, where force exhibits a drop. The bioyield significantly decreases with the date of the harvesting. There is no evidence of the dependence of this parameter on the direction of loading. The same result is approximatively valid for apparent modulus of elasticity $E$. The force-displacement curves have been successfully modelled by non-linear mathematical models.
\end{abstract}

peach, strength properties, shape analysis, maturity

The quality of peaches at consumption depends highly on maturity and ripeness at harvest. There are three stages of peach fruit development. Following bloom, Stage I is a period of cell division and rapid fruit growth, during which the endocarp accounts for most of the size increase (Ryugo, 1988). Stage I ceases about 50 to 60 days after bloom. Stage II, which can last for varying lengths of time, is marked by pit hardening and slow fruit growth, whereas rapid growth until harvest occurs in Stage III. Fruit growth during the final period is through enlargement of the mesocarp cells (Ryugo, 1988). Stage III usually lasts approximately six weeks see Fig. 1 .

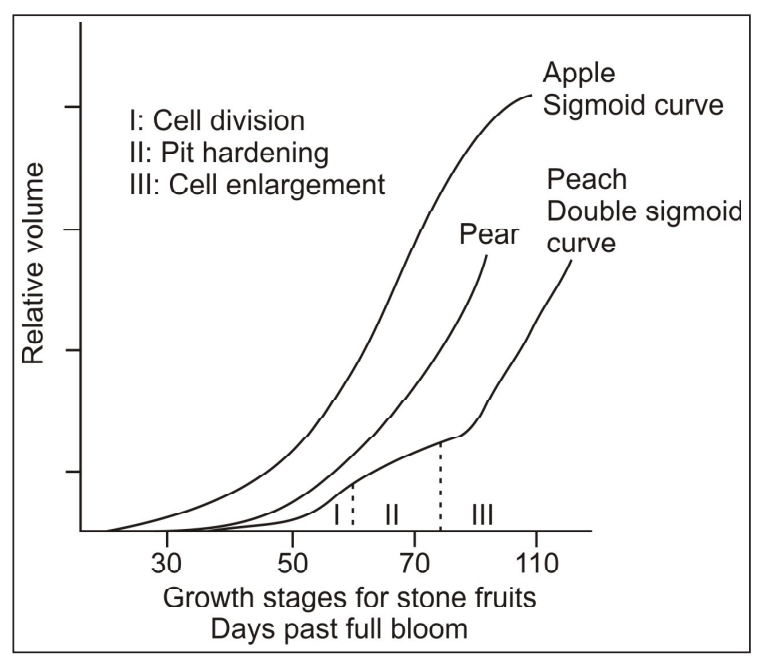

1: Schematic of the fruit growth curves (redesigned picture from Jackson, 1975) 
As peach fruit development is completed, the fruit become mature and subsequently ripen. In this study, the terms "mature" and "physiological maturity" refer to the stage of development where a fruit has the ability to "ripen". Maturity must occur on the tree, while ripening can occur on or off the tree. Mature is synonymous with completeness of development, while the term ripe implies readiness for use (Haller, 1952). Changes that occur during maturation and ripening include a gradual decrease in flesh firmness, a change in ground colour from mainly green to mainly yellow, increases in the area and intensity of overlying red colour (blush), a change in flesh colour from whitish green to pale yellow, and a marked increase in flavour. Changes in quality occurring during maturity and ripening include increases in sugar concentration and aromatic compounds, decreases in acid concentration, and development of a less crunchy texture (Lott, 1965).

Next aspects of the fruit quality consists in the regularity of fruit shape and proportion of the compartments of the fruit of interest to the consumers (mesocarp in the case of peach). In general, selection criteria of peach fruit should also focus on obtaining a round fruit with a little round well-centered stone, even though some programs concern in obtaining a flatish fruit (Pascal, 1998).

The present paper is focused on the investigation of the peach shape and on the strain behaviour of the whole peaches, which were harvested at the different days.

\section{MATERIAL AND METHODS}

\section{Peach shape evaluation}

The shape of the peach is generally very complicated - see Fig. 2 as an example. The complete geometrical model must be based on the 3D scanning of this fruit. Such procedure is very expensive. This is why another approach have been used.

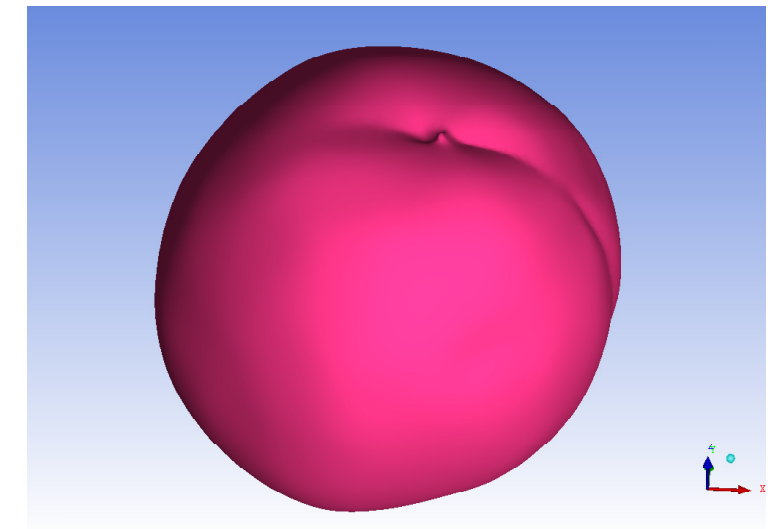

2: 3D scan of the peach

In order to describe the peach shape the three dimensions of the whole fruit and of the stone, i.e. height $(H)$, cheek diameter (Dc) and suture diameter (Ds) are evaluated - see Fig. 3.

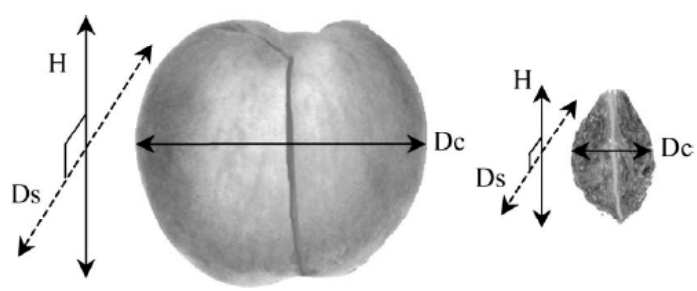

3: Three different dimensions measured on the fruit and the stone

Global shape of the fruit and stone were characterized by calculating the $H / D$ s, $H / D c$ and $D c / D s$ ratios. When the ratio was found to be 1 , the shape was globally round. When they were different from 1 , the shape was oval.

For the experiments the peaches of the Red Haven variety have been used. Peaches have been harvested on different days during July, 2007. The total mass of the peaches, $m$, and the parameters shown in the Fig. 3 have been evaluated. The example of the variation of these parameters is given in the Fig. 4.

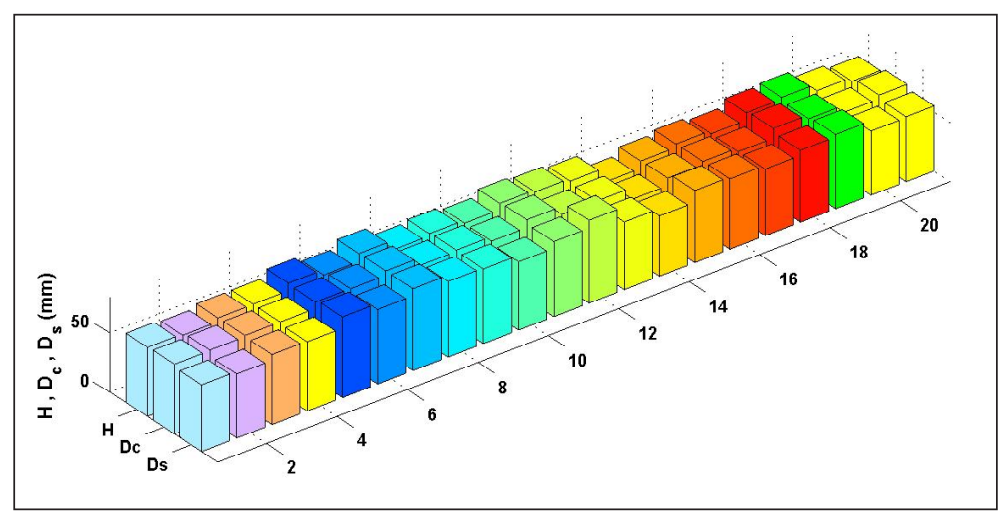

4: The parameters of the shape of the peach. Peaches harvested on July 12, 2007 
The more detailed description of the peach shape is based on the analysis of the digital photo. Such methods are valuable for researchers in various fields, such as genetics, agriculture, ecology and taxonomy. Elliptic Fourier descriptors (EFDs), originally proposed by Kuhl and Giardina (1982), can delineate any type of shape with a closed twodimensional contour. EFDs have been effectively applied to the analysis of various biological shapes in animals (Rohlf and Archie 1984; Ferson et al. 1985; Bierbaum and Ferson, 1986; Diaz et al., 1989; Liu et al. 1996; Laurie et al., 1997) and plants (White et al., 1988; McLellan, 1993; Furuta et al. 1995; Ohsawa et al. 1998; Iwata et al., 1998; Iwata et al., 2000; Toyohara et al., 2000; Iwata et al., 2002; Uga et al., 2003; Iwata et al., 2004a, 2004b; Yoshioka et al., 2005a, 2005b, 2006a, 2006b). Evaluation based on EFDs also gives sufficient resolution, in combination with quantitative genetic analysis, to elucidate the inheritance of biological shapes

\section{Compression test}

The whole peaches has been compressed between two plates at the constant cross - head velocity $20 \mathrm{~mm} / \mathrm{min}$ using the TIRA testing machine - see Fig. 5 as an example.

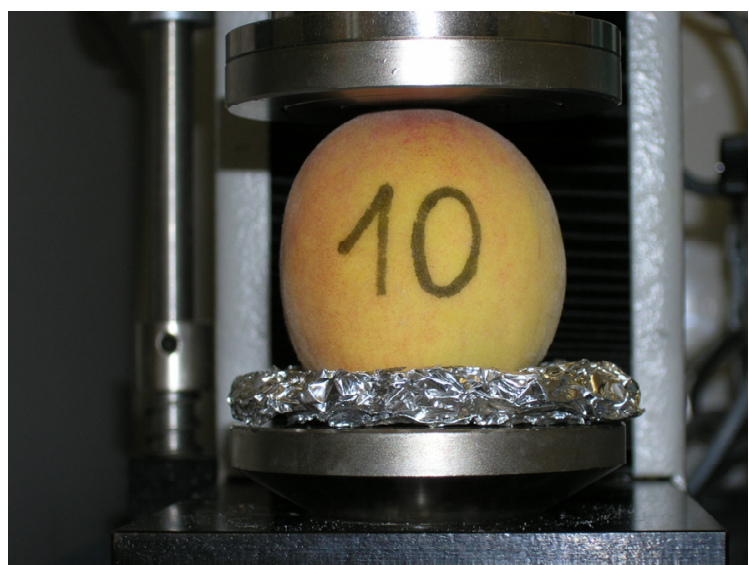

5: Photo of the compression test

The peaches have been loaded in the main directions shown in the Fig. 3. Force-deformation curves were recorded by the data acquisition system and the strength properties were measured by these curves.

\section{RESULTS AND DISCUSSION}

The values of $H / D s, H / D c$ and $D c / D s$ ratios obtained for peaches harvested on the different days are shown in Fig. 6. It is evident that there is no, or nearly no, differences between peaches harvested at the different days. The term of the harvesting exhibits no influence on the peach shape. The shape of the all tested peaches is very close to round one - see Fig. 7. Figs. 8-10 demonstrate that the parameters of the shape are mutually dependent.

We established a similar global linear relationship for peaches harvested on different days between the dimensions taken in pairs (Fig. 8-10). Slopes of these relationships were not significantly different from 1 .

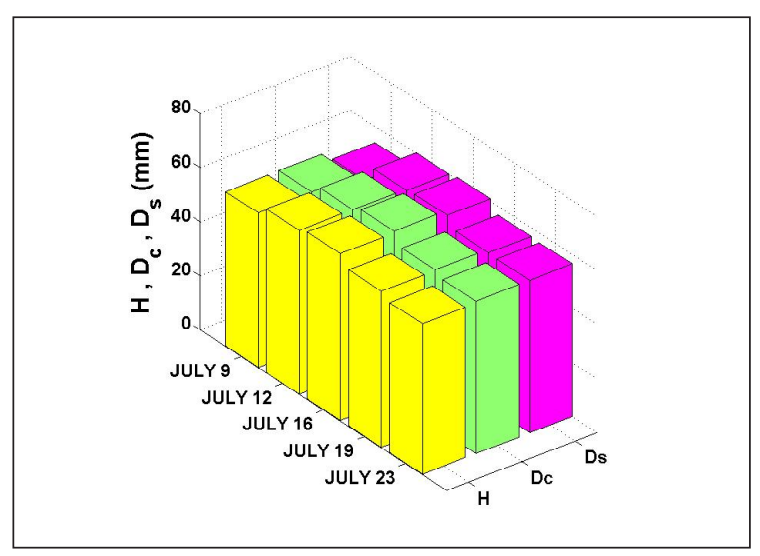

6: The average values of the parameters describing the peach shape

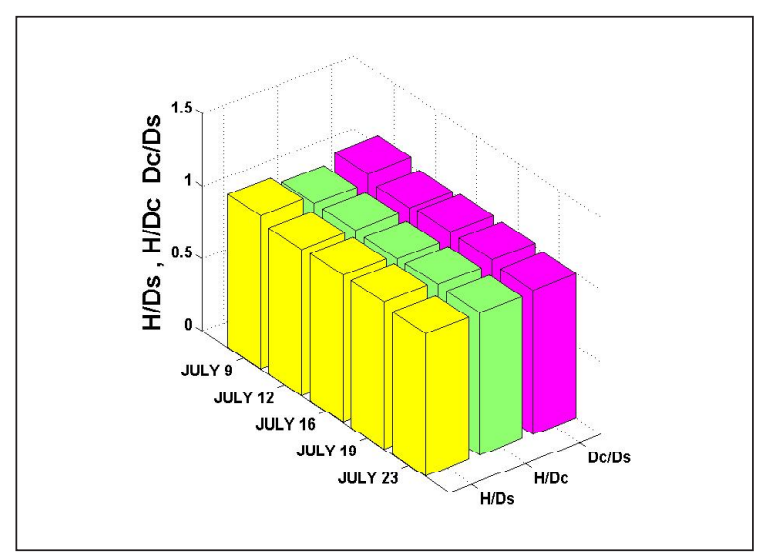

7: The difference between round and real shape 


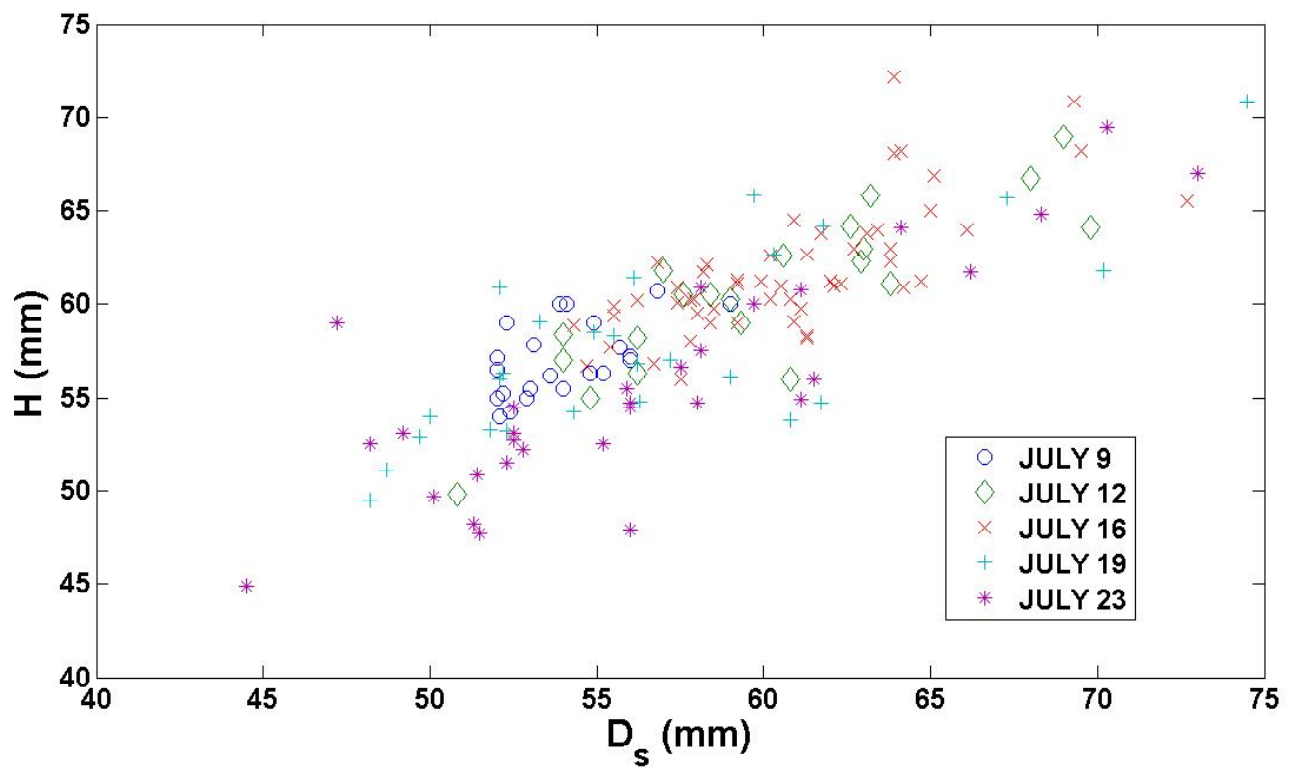

8: The relation between parameters describing peach shape

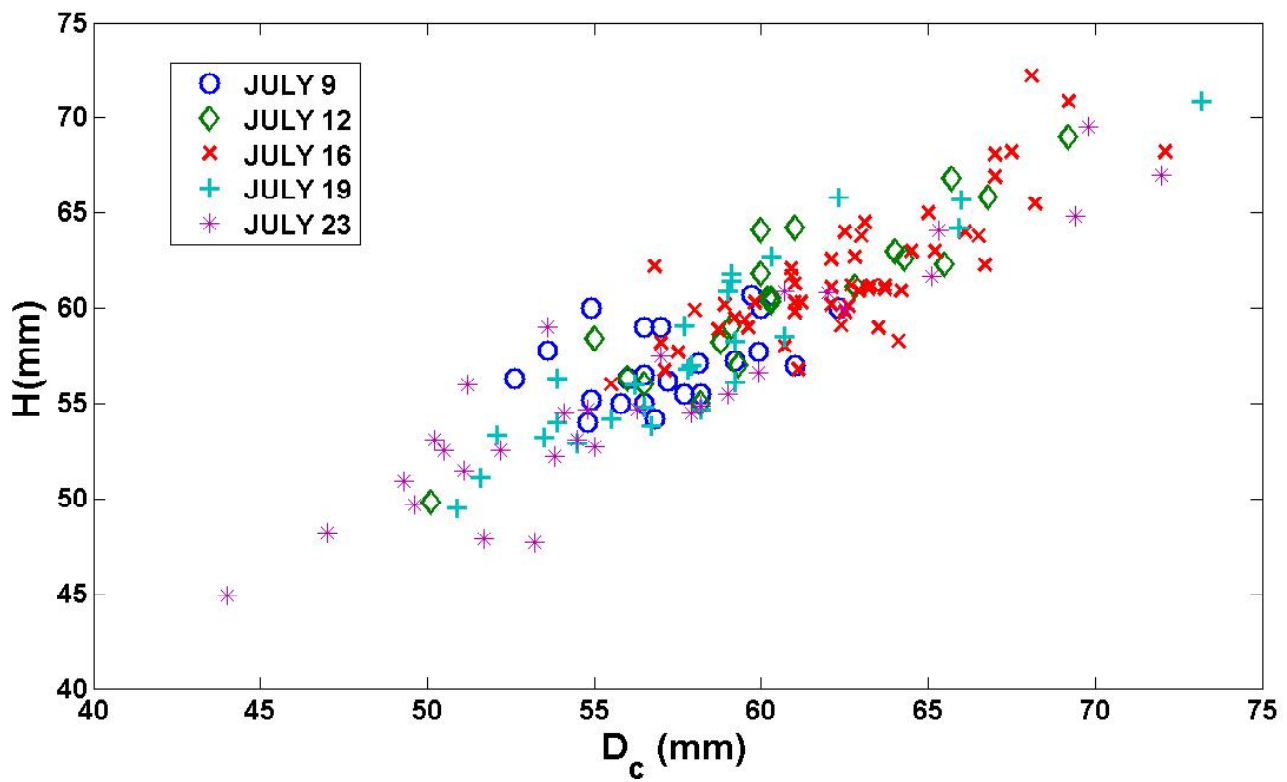

9: The relation between parameters describing peach shape

The analysis of the digital image by the method mentioned above enables to obtain a description of the peach countour in the form:

$$
x(\varphi)=r \cos \varphi, y(\varphi)=r \sin \varphi,
$$

where $r$ is the radius and $\varphi$ the polar angle. The knowledge of this description can be used for the evaluation of the radius of the curvature $R$. The knowledge of this parameter is than very useful e.g. for the evaluation of the results of the compression test. 


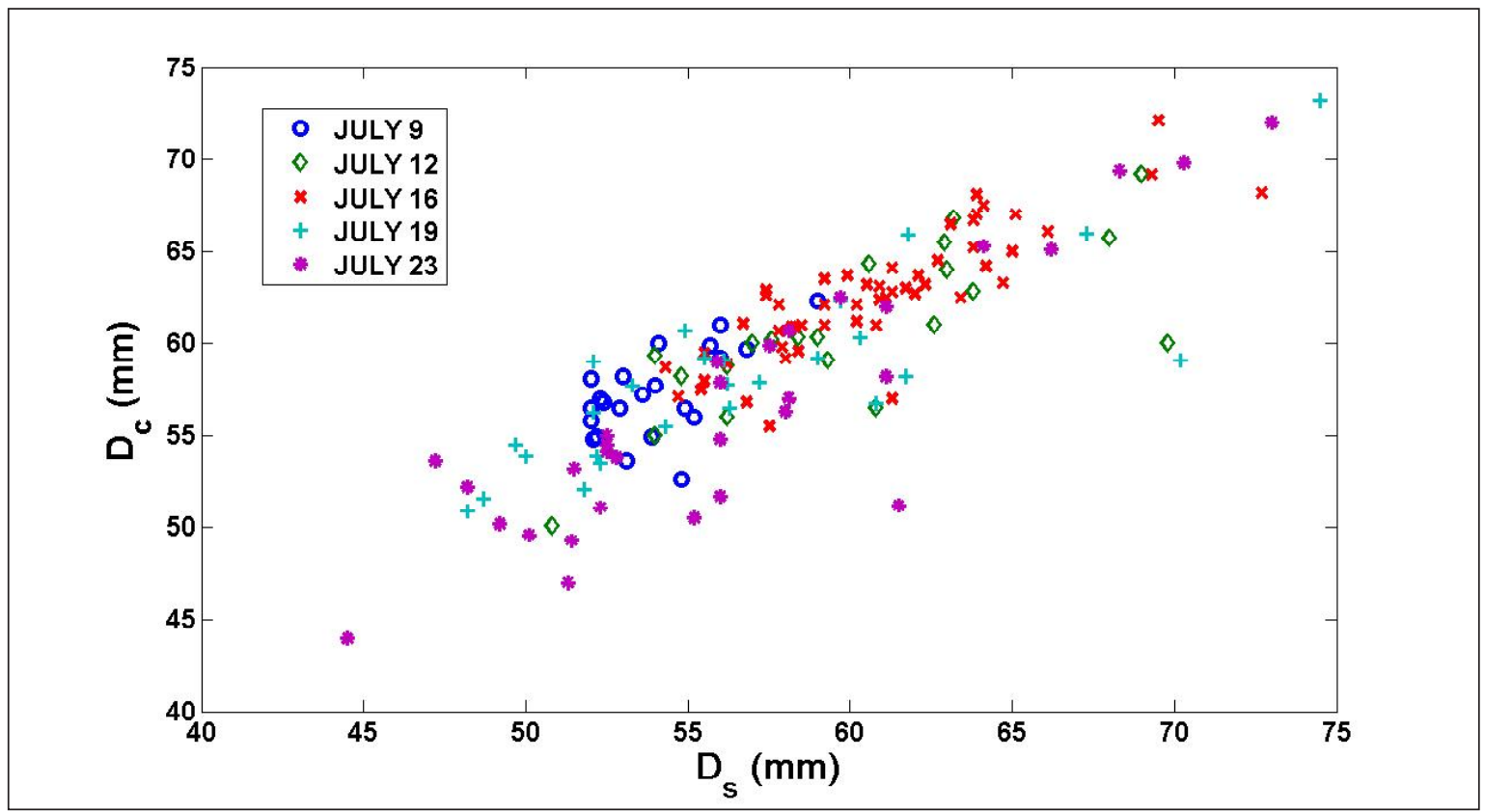

10: The relation between parameters describing peach shape

\section{Compression test}

Examples of the force-displacement curves are shown in the Fig. 11.

The curves are characterised by certain monotonic increase and the point where force exhibits a drop.
This point is usually termed as the bioyield. Before the bioyield point the dependence of the force $F$ on the displacement $x$ is well fitted by the non-linear function:

$$
F(N)=a x^{3}+b x^{2}+c x .
$$

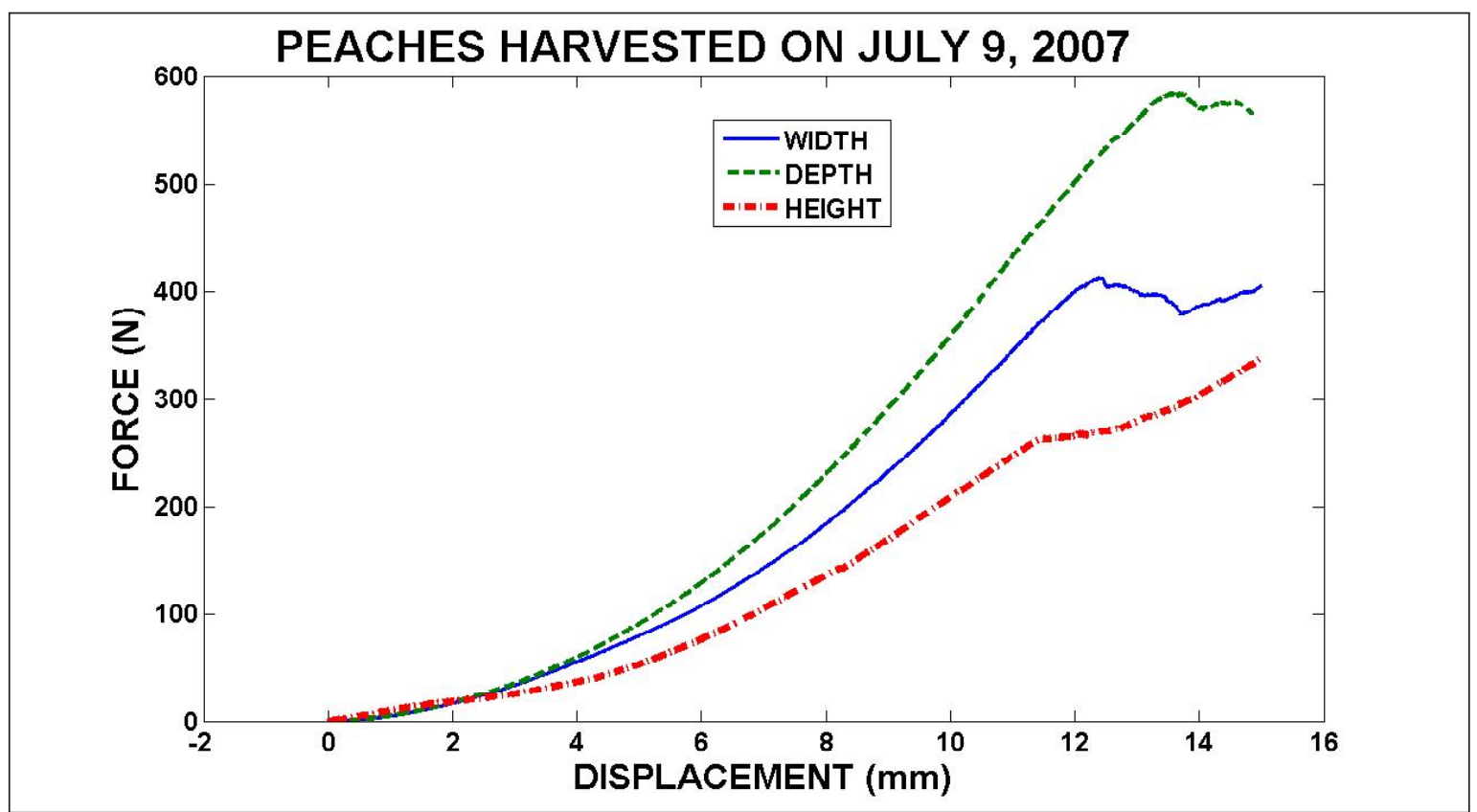

11: The depence force - displacement 
At the bioyield the bruise of the peach starts. The next parameter is the apparent modulus of elasticity, which can be evaluated as the tangent elastic modulus mid-way along the force deformation curve between the origin and the yield point from the following equation:

$$
E=\frac{0.338 K_{u}^{\frac{3}{2}} F\left(1-v^{2}\right)}{x^{\frac{3}{2}}}\left(\frac{1}{R}+\frac{1}{R^{\prime}}\right),
$$

where $E$ is the apparent modulus of elasticity in $\mathrm{Pa}, F$ is the applied compressive force in N, $\mu$ is Poisson's ratio (dimensionless), $x$ is the displacement under compression in $\mathrm{m}, K_{u}$ is the constant, $R$ is the minimum radius of curvature of the sample at the point of contact in $\mathrm{m}, R^{\prime}$ is the maximum radius of curvature in $\mathrm{m}$.

The values of of the bioyield are displayed in Fig.12.

It is evident that the bioyield significantly decreases with the date of the harvesting. This fact is valid since certain days. There is no evidence of the dependence of this parameter on the direction of loading.

The same result is approximatively valid also for the apparent modulus of elasticity E - see Fig. 13.

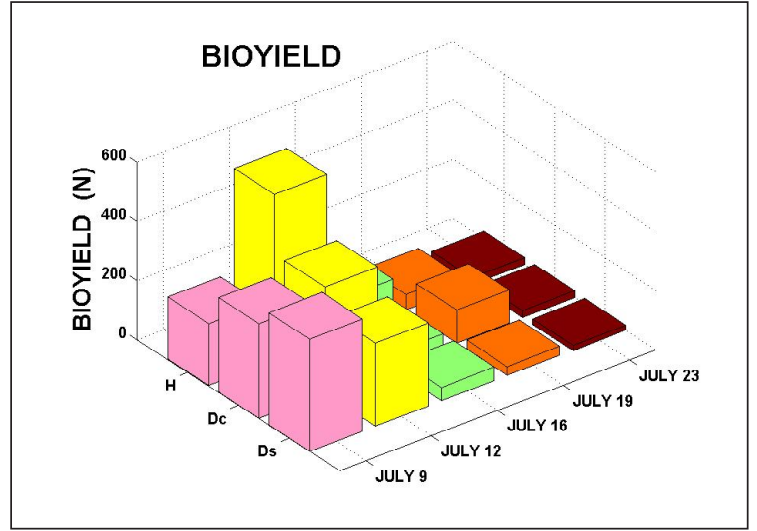

12: Bioyield of the peaches - an average value from about 5 measurements

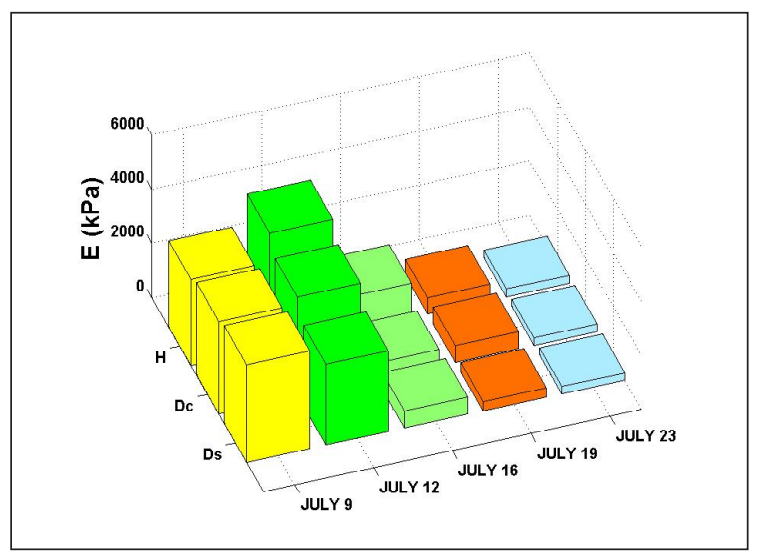

13: Apparent modulus of elasticity of the peaches - an average value from about 5 measurements

\section{SUMMARY}

Shape of the peaches of the Red Haven variety has been characterized by calculating the $H / D s, H / D c$ and Dc/Ds ratios. Detailed description of the peach shape has been based on the Elliptic Fourier analysis (EFDs) of the digital photos. Compression tests have been also perforemd - the whole peaches have been compressed between two plates at the constant cross-head velocity $20 \mathrm{~mm} / \mathrm{min}$.

The results suggest that the peach shape appeared stable and round. The day of the harvesting plays no or only minor role in the development of the main parameters which describe the peach shape. Because the fruit shape is determined by mesocarp growth in the various directions of the fruit, one can conclude that this growth is different in the different directions in the peach. This conclusion follows from the shape of the stone. The more detailed examination of this effect will be subject of the forthcoming papers.

It was found that the peaches exhibited superior strength properties at the beginning of the harvest, and that after about 7 days they softened rapidly. Therefore, it is advisable to do most handling, such as packing and transportation, within about 7 days after beginning of the harvest.

\section{SOUHRN}

Hodnocení tvarů a mechanických vlastností broskví Red Haven v různých stadiích zralosti V rámci této práce byly hodnoceny tvary a mechanické vlastnosti broskví odrůdy Red Haven sklízených v různých fázích zralosti v červenci 2007. Tvar plodů a pecek byl popsán vypočtenými poměrovými parametry $H / D$ s, $H / D c$ a Dc/Ds. Je zřejmé, že neexistuje zřejmý kvantifikovatelný rozdíl v tvarech broskví sklízených v různých termínech (stadiích zralosti). Tvar téměř všech broskví sledovaných v rámci tohoto výzkumu byl téměř kulový. Detailnější rozbor tvaru broskví byl založen na obrazové analýze digitálních snímků plodů. Použita byla tzv. Eliptická Fourierova analýza (EFD). Ana- 
lýza vedla k výpočtu poloměrů křivosti. Tento parametr byl dále využit při hodnocení mechanických vlastností broskví. Celé plody byly stlačovány ve všech hlavních směrech mezi dvěma deskami (hlavicemi) zkušebního stroje rychlostí $20 \mathrm{~mm} / \mathrm{min}$. Byly získány křivky závislostí síla-posunutí, které byly následně modelovány pomocí nelineárních modelů. Křivky vykazovaly počáteční lineární region nárůstu. Za tímto regionem následoval ve všech případech bod, kdy nastal pokles síly. Tento bod je obvykle nazýván „bioyield“. Od fáze „bioyield“ začínají na plodech vznikat otlaky. Je zřejmé, že poloha bodu „bioyield“ je závislá na datu sklizně - jeho hodnota se výrazně snižuje s datem. Tento závěr je platný až od určitého stupně zralosti. Nebyla zaznamenána závislost tohoto parametru na směru zatěžování. Obdobný závěr je možno vyvodit i pro vypočtený zdánlivý modul elasticity. Z výsledkủ měření vyplývá, že broskve vykazují výborné mechanické pevnostní charakteristiky během první sedmi dnů sklizňové sezony. V dalších dnech se tyto vlastnosti výrazně zhoršují. Proto je doporučováno, aby byla většina manipulačních operací (balení, transport apod.) prováděna na začátku sklizně.

broskev, mechanické vlastnosti, analýza tvaru, zralost

\section{ACKNOWLEDGEMENTS}

The research has been supported by the Grant Agency of the Czech Academy of Sciences under Contract No. IAA201990701.

\section{REFERENCES}

BIERBAUM, R. M. and FERSON, S., 1986: Do symbiotic pea crabs decrease growth rate in mussels?, Biol. Bull. 170, 51-61

DIAZ, G., ZUCCARELLI, A., PELLIGRA, I. and GHIANI, A., 1989: Elliptic Fourier analysis of cell and nuclear shapes. Comp Biomed Res 22, 405-414

FERSON, S., ROHLF, F. J. and KOEHN, R. K., 1985: Measuring shape variation of two dimensional outlines. Syst Zool 34, 59-68

FURUTA, N., NINOMIYA, S., TAKAHASHI, S., OHMORI, H. and UKAI, Y., 1995: Quantitative evaluation of soybean (Glycine max L., Merr.) leaflet shape by principal component scores based on elliptic Fourier descriptor. Breed Sci 45, 315-320

HALLER, M., 1952: Handling, transportation, storage, and marketing of peaches. U.S.D.A Circ. No. 21

IWATA, H., NIIKURA, S., MATSUURA, S., TAKANO, Y. and UKAI, Y., 1998: Evaluation of variation of root shape of Japanese radish (Raphanus sativus L.) based on image analysis using elliptic Fourier descriptors. Euphytica 102, 143-149

IWATA, H., NIIKURA, S., MATSUURA, S., TAKANO, Y. and UKAI, Y., 2000: Diallel analysis of root shape of Japanese radish (Raphanus sativus L.) based on elliptic Fourier descriptors. Breed Sci 50, 73-80

IWATA, H., NESUMI, H., NINOMIYA, S., TAKANO, Y. and UKAI, Y., 2002: Diallel analysis of leaf shape variations of citrus varieties based on elliptic Fourier descriptors. Breeding Science 52, 89-94

IWATA, H., NIIKURA, S., MATSUURA, S., TAKANO, Y. and UKAI, Y., 2004a:Genetic control of root shape at different growth stages in radish (Raphanus sativus L.). Breeding Science 54, 117-124

IWATA, H., NIIKURA, S., MATSUURA, S., TAKANO, Y. and UKAI, Y., 2004b: Interaction between genetic effects by soil type in diallel analysis of root shape and size of Japanese radish (Raphanus sativus L.). Breeding Science 54, 313-318
IWATA, H. and UKAI, Y., 2002: SHAPE: A computer program package for quantitative evaluation of biological shapes based on elliptic Fourier descriptors. Journal of Heredity 93, 384-385

JACKSON, J. E. and BLASCO, A. B., 1975: Effects of rootstocks and crop load on fruit size and quality of Cox's Orange Pippin and Worcester Pearmain. Rpt. E. Malling Res. Sta., p. 45

KUHL, F. P. and GIARDINA, C. R., 1982: Elliptic Fourier features of a closed contour. Comp Graph Ima Proc 18, 236-258

LAURIE, C. C, TRUE, J. R., LIU, J. and MERCER, J. M., 1997: An introgression analysis of quantitative trait loci that contribute to a morphological difference between Drosophila simulans and D. mauritiana. Genetics 145, 339-348

LIU, J., MERCER, J. M., STAM, L. F., GIBSON, G. and LAURIE, C.C., 1996: Genetic analysis of a morphological shape difference in the male genitalia of Drosophila simulans and D. mauritiana. Genetics 142, 1129-1145

LOTT, R., 1965: The relationship between stage of maturation and degree of quality in apple and peach fruits. Ill. St. Hort Soc. 99, 139-151

PASCAL, T., 1998: Peach breeding in France. Acta Hort. 465, 117-123

QUILOT, B., KERVELLA, J. and GÉNARD, M., 2004: Shape, mass and dry matter content of peaches of varieties with different domestication levels. Scientia Horticulturae 99, 387-393

ROHLF, F. J. and ARCHIER, J. W., 1984: A comparison of Fourier methods for the description of wing shape in mosquitoes (Ritera culicidae). Syst Zool 33, 302-317

RYUGO, K, 1988.: Fruit culture: Its science and art. John Wiley \& Sons, New York

UGA, Y., FUKUTA, Y., CAI, H. W., IWATA, H., OHSAWA, R., MORISHIMA, H. and FUJIMURA, T., 2003: Mapping QTLs influencing rice floral morphology using recombinant inbred lines derived 
from a cross between Oryza sativa L. and O. rufipogon Griff. Theoretical and Applied Genetics 107, 218-226

WHITE, R., RENTICE, H. C. and VERWIST, T., 1988: Automated image acquisition and morphometric description. Can J Bot 66, 450-459

YOSHIOKA, Y., IWATA, H., OHSAWA, R., and NINOMIYA, S.,2005a: Quantitative evaluation of flower colour pattern by image analysis and principal component analysis of Primula sieboldii E. Morren. Euphytica 139, 179-186

YOSHIOKA, Y., IWATA, H., OHSAWA, R., and NINOMIYA, S., 2005b: Quantitative evaluation of the petal shape variation in Primula sieboldii caused by breeding process in the last 300 years. Heredity 94, 657-663

YOSHIOKA, Y., IWATA, H., FUKUTA, N., OHSAWA, R. and NINOMIYA, S., 2006a: Quantitative evaluation of petal shape and picotee color pattern in $l i$ sianthus by image analysis. Journal of the American Society for Horticultural Science 131, 261-266

YOSHIOKA, Y., IWATA, H., HASE, N., MATSUURA, S., OHSAWA, R. and NINOMIYA, S., 2006b: Genetic combining ability of petal shape in garden pansy (Viola $\mathrm{x}$ wittrockiana Gams) based on image analysis. Euphytica 151, 311-319

Address

Ing. Libor Severa, Ph.D., Ústav techniky a automobilové dopravy, Mendelova zemědělská a lesnická univerzita v Brně, Zemědělská 1, 61300 Brno, Česká republika, e-mail: severa@mendelu.cz 